Pengembangan Perangkat Pembelajaran IPA SD/MI Menggunakan Inkuiri Terbimbing Untuk

Melatih Keterampilan Berpikir Kritis Siswa Pada Materi Struktur Tubuh

\author{
Abdul Gani ${ }^{1)}$ \\ e-mail: abganaja@gmail.com
}

\begin{abstract}
This research aims to bring out science teaching material by using guided inquiry which is feasible to facilitate student's critical thinking skill. The development used 4D model and have been implementation in four year's class of MI Hidayatussibyan on first semester 2017/2018 with One-Group Pretes-Posttest Design. Data were collected through validation, observation, test, and questionnaire method. The data was analized by using quantitative and qualitative descriptive analysis. Results showed: 1) the teaching material developed which involve syllabus, lesson plan, textbook, worksheet, conceptual understanding test and critical thinking skill test are in valid category; 2) the material are categorized as practice where lesson plan was carried out, and student's activity followed stages of guide inquiry model; and 3) they are effective where: (a) the increasing of conceptual understanding of students can be observed by the increasing of classical completeness from 46,46 to 87,15 ; (b) critical thinking skill went up with $\mathrm{n}$-gain of high category $(0,52)$; and (c) student's respond to guided inquiry instruction is in good category. Therefore, the material is feasible to facilitate student's critical thinking skill.
\end{abstract}

Keywords: Perangkat Pembelajaran, inkuiri terbimbing, berpikir kritis.

\title{
Pendahuluan
}

Guru merupakan faktor penentu pertama yang menentukan keberhasilan pembelajaran menurut kurikulum 2013 yaitu kesesuaian kompetensi pendidik dan tenaga kependidikan (PTK) dengan kurikulum dan buku teks ${ }^{1}$. Persiapan diri guru menjadi hal yang sangat penting karena guru akan mengemban amanah pembelajaran yang bertujuan mendorong peserta didik mampu lebih baik dalam melakukan observasi, bertanya, bernalar, dan mengkomunikasikan terhadap apa yang mereka peroleh atau mereka ketahui setelah menerima materi pelajaran ${ }^{2}$.

Guru dituntut untuk mampu membuat perangkat pembelajaran, menguasai kurikulum, menguasai materi, menguasai strategi dan metode, dan tidak kalah pentingnya guru juga harus mampu mengelola kelas sedemikian rupa sehingga kegiatan pembelajaran yang dituntut dalam kurikulum 2013 untuk menggunakan tiga prinsip yaitu: (1) berpusat pada peserta didik, (2) mengembangkan kreativitas peserta didik, (3) menciptakan kondisi menyenangkan dan menantang, dapat terlaksana ${ }^{3}$. Prinsip tersebut dapat berjalan efektif bila pengorganisasian dan penyampaian materi sesuai dengan kesiapan mental siswa dan dilengkapi dengan adanya perangkat pembelajaran untuk mendukung keaktifan dan keterampilan berpikir kritis siswa. Perangkat pembelajaran

1 Krisnawati, N.M. (2014). Pengembangan perangkat pembelajaran biologi model kooperatif dengan pendekatan scientific untuk melatih berpikir kritis siswa SMA (Tesis magister pendidikan tidak dipublikasikan). Universitas Negeri Surabaya

${ }^{2}$ BSNP. (2013). Permendikbud Nomor 81A tahun 2013 tentang implementasi kurikulum. Jakarta: BSNP

${ }^{3}$ Ibid. 
mempunyai peran penting dalam pembelajaran, yaitu dapat membantu kegiatan belajar mengajar menjadi lebih efektif. Sejalan dengan hal tersebut, Ibrahim ${ }^{4}$ mengatakan bahwa, kegiatan belajar haruslah dirancang suatu aktivitas agar terjadi pengembangan sikap, pengetahuan, dan keterampilan berpikir kritis dalam kombinasi dan penekanan yang bervariasi. Hal ini bertujuan untuk melaksanakan tuntutan kurikulum 2013 yang menekankan pada proses pembelajaran harus terdiri atas lima pengalaman belajar pokok yaitu (1) mengamati, (2) menanya, (3) mengumpulkan informasi, (4) mengasosiasi, dan (5) mengkomunikasikan ${ }^{5}$.

Penggunaan perangkat pembelajaran yang menekankan pada kelima pokok pengalaman belajar tersebut bertujuan untuk mempersiapkan siswa menghadapi kehidupan dan lingkungan abad 21 yang membutuhkan beberapa keterampilan yaitu keterampilan kognitif, keterampilan interpersonal, dan keterampilan intrapersonal ${ }^{6}$. Berkaitan dengan hal tersebut, keterampilan berpikir kritis sangat penting untuk dilatih dan diajarkan pada siswa karena keterampilan berpikir kritis merupakan salah satu bagian dari keterampilan kognitif ${ }^{7}$. Selain itu, pentingnya melatih dan mengajarkan keterampilan berpikir kritis pada siswa disebabkan oleh implikasi pergeseran paradigma pendidikan abad 21 dari pembelajaran yang hanya fokus pada penguasaan pengetahuan ke pembelajaran holistik yang berbasis pada keterampilan, keseimbangan nilai, dan literasi untuk memecahkan permasalahan kehidupan ${ }^{8}$.

Sejalan dengan uraian di atas, penggunaan perangkat pembelajaran yang menekankan pada kelima pokok pengalaman belajar tersebut diharapkan dapat memberikan kontribusi yang positif, yaitu semakin meningkatnya aktivitas siswa dan waktu menjadi lebih efektif terhadap pencapaian hasil belajar. Supaya perangkat pembelajaran tersebut dapat terkonsepsi dengan baik, sehingga mampu melatih keterampilan berpikir kritis siswa, maka perangkat tersebut dapat dikembangkan dengan menggunakan model yang mendukung siswa untuk aktif melakukan keterampilan berpikir kritisnya. Aktivitas bertanya ketika siswa mengikuti proses pembelajaran merupakan salah satu bentuk siswa untuk mendapatkan pemahaman. Sementara itu, tujuan dari berpikir kritis adalah untuk mencapai pemahaman yang mendalam ${ }^{9}$. Berkaitan dengan hal tersebut, Mainali

\footnotetext{
${ }^{4}$ Ibrahim, M. (2014). “Inovasi pendidikan sains dalam kurikulum 2013”. Makalah disajikan pada Seminar Nasional Pendidikan Sains, Surabaya, Tanggal 18 Januari 2014

${ }^{5}$ Ibid

${ }^{6}$ Nebraska Department of Education. (2007). $21^{\text {st }}$ Century Education Frame Work, www.21st-centuryskills.org.

${ }^{7}$ Norris, S.P. (1985). "Synthesis of Research on Critical Thinking". Educational Leadership. 1985. Pp.40-45

${ }^{8}$ Wasis. (2015). "Hasil Pembelajaran Sains di Indonesia: Problem dan Upaya Mengatasinya”. Makalah disajikan pada Seminar Nasional Pendidikan Sains, Surabaya, Tanggal 24 Januari 2015

${ }^{9}$ Johnson, E.B. (2008). Contextual teaching \& learning. Bandung: MLC
} 
mengungkapkan bahwa berpikir kritis dapat meningkatkan pemahaman siswa, dan kemampuan memecahkan masalah ${ }^{10}$.

Pembelajaran di sekolah harus bergeser dari diberi tahu menjadi aktif mencari tahu serta siswa harus dibekali dengan kemampuan berpikir kritis. Berpikir kritis merupakan proses yang terarah, jelas dan terorganisasi dalam kegiatan mental seperti memecahkan masalah, mengambil keputusan, menganalisis asumsi dan melakukan penelitian ilmiah ${ }^{11}$. Seseorang dikatakan berpikir kritis apabila mampu menunjukkan kecakapan mengidentifikasi masalah yang signifikan, menganalisis argumen, mengevaluasi dengan membandingkan kebenaran dan interpretasi, menemukan unsur-unsur yang diperlukan dalam membuat keputusan dari hasil yang diperoleh ${ }^{12}$.

Hasil observasi yang dilakukan pada tanggal 20 Agustus 2017 di sekolah yang akan menjadi sasaran penelitian (MI Hidayatussibyan NW Sengkerang), saat ini perangkat pembelajaran belum melaksanakan amanah kurikulum 2013 yaitu proses pembelajaran yang tercermin dalam rencana pelaksanaan pembelajaran (RPP) siswa tidak diajarkan untuk melakukan kegiatan 5M (mengamati, menanya, mengumpulkan informasi, mengasosiasi, dan mengkomunikasikannya) dan belum terdapat aktivitas yang melibatkan siswa untuk berpikir kritis, serta masih saja terjadi kegiatan pembelajaran yang didominasi oleh guru sehingga terlihat pembelajaran yang diikuti siswa tidak melakukan kegiatan berpikir kritis selama kegiatan belajar mengajar berlangsung.

Mengingat kondisi tersebut, guru harus menguasai prinsip-prinsip pembelajaran, penggunaan media pembelajaran, buku ajar, lembar kerja siswa (LKS), serta memilih dan menggunakan model pembelajaran ${ }^{13}$. Salah satu model pembelajaran yang dapat merangsang keterlibatan siswa secara aktif dalam proses pembelajaran adalah dengan menggunakan pembelajaran inkuiri terbimbing. Hal tersebut diperkuat oleh Firdaus yang menyatakan bahwa pembelajaran inkuiri terbimbing merupakan pembelajaran yang dapat membantu siswa untuk mengembangkan keterampilan melakukan inkuiri dan keterampilan berpikir kritisnya ${ }^{14}$. Sejalan dengan hal tersebut, pembelajaran inkuiri terbimbing disusun dengan tujuan untuk meningkatkan pemahaman konsep dan kinerja ilmiah siswa ${ }^{15}$.

${ }^{11}$ Ibid

${ }^{12}$ Ibid

${ }^{13}$ Mulyasa. (2013). Pengembangan dan implementasi kurikulum 2013. Bandung: Remaja Rosdakarya

${ }^{14}$ Firdaus, L. (2014). Pengembangan perangkat pembelajaran sains berorientasi pada guided inquiry untuk memberdayakan keterampilan berpikir dan pemahaman konsep siswa SMP (Tesis magister pendidikan tidak dipublikasikan). Universitas Negeri Surabaya

${ }^{15}$ Dewi, Sadia, \& Ristiati. (2013). "Pengembangan perangkat pembelajaran IPA terpadu dengan setting inkuiri terbimbing untuk meningkatkan pemahaman konsep dan kinerja ilmiah”. E-Journal program pascasarjana universitas pendidikan ganesha. Vol 3 Tahun 2013
}

${ }^{10}$ Mainali, B.P. (2011). "Critical thinking for quality education". Academic voices a multidisciplinary journal. 
Materi IPA MI Hidayatussibyan NW Sengekrang Kelas IV Semeter I pada pokok bahasan struktur tubuh merupakan materi yang tercantum dalam Kompetensi Dasar 1.1. yang menjadi penjelasan dari Kompetensi Inti 1 yang menuntut siswa untuk memahami, menerapkan, menganalisis pengetahuan faktual, konseptual, prosedural berdasarkan rasa ingintahunya terhadap segala sesuatu yang berkaitan dengan kerangka tubuh manusia sehingga siswa bisa mengolah, menalar, dan menyajikan informasi dalam menyeselesaikan masalah yang berkaitan dengan kerangka tubuh manusia. Dengan demikian, siswa dapat melatih keterampilan berpikir kritisnya melalui ilmu ini dengan baik, maka diperlukan perangkat pembelajaran yang baik pula.

Berdasarkan hal yang telah diuraikan tersebut, maka akan dilakukan suatu penelitian tentang pengembangan perangkat pembelajaran IPA SD/MI menggunakan inkuiri terbimbing untuk melatih keterampilan berpikir kritis siswa pada materi pokok kerangka tubuh manusia. Melalui perangkat pembelajaran yang akan dikembangkan dapat memfasilitasi siswa untuk menerapkan keterampilan berpikir kritis dan keterampilan inkuiri ilmiah untuk memahami materi atau kompetensi yang akan dipelajari. Selanjutnya dengan keterampilan berpikir kritis tersebut, siswa dapat mengembangkan kemampuannya dalam menyelesaikan masalah, yang pada akhirnya dengan bekal tersebut siswa diharapkan dapat beradaptasi dengan era globalisasi teknologi dan informasi.

\section{Hasil Penelitian}

\section{Validasi Perangkat Pembelajaran}

Perangkat pembelajaran yang dikembangkan meliputi silabus, RPP, buku ajar siswa, LKS, tes pemahaman konsep, dan tes keterampilan berpikir kritis. Perangkat pembelajaran tersebut telah divalidasi oleh para pakar dengan hasil sebagai berikut:

Tabel 1.

Hasil Validasi Perangkat Pembelajaran

\begin{tabular}{|c|l|c|}
\hline No & \multicolumn{1}{|c|}{ Perangkat } & Keterangan \\
\hline 1. & Silabus & Valid \\
\hline 2. & RPP & Valid \\
\hline 3. & Buku Ajar Siswa & Sangat Valid \\
\hline 4. & $\begin{array}{l}\text { Lembar Kerja Siswa } \\
\text { (LKS) }\end{array}$ & Valid \\
\hline 5. & $\begin{array}{l}\text { Tes Pemahaman } \\
\text { Konsep }\end{array}$ & Valid \\
\hline 6. & $\begin{array}{l}\text { Tes Keterampilan } \\
\text { Berpikir Kritis }\end{array}$ & Valid \\
\hline
\end{tabular}




\section{Hasil Validasi Silabus}

Silabus yang dikembangkan dalam penelitian ini mengacu pada Permendikbud Nomor 65 Tahun 2013 tentang Standar Proses Pendidikan Dasar dan Menengah. Silabus yang dikembangkan telah memuat kriteria yang telah ditentukan dalam Permendikbud tersebut yaitu memuat (a) identitas mata pelajaran, (b) identitas sekolah, (c) kompetensi inti, (d) kompetensi dasar, (e) materi pokok, (f) kegiatan pembelajaran, (g) penilaian, (h) alokasi waktu, dan (i) sumber belajar.

Berdasarkan data dan analisis data hasil validasi silabus yang telah dilakukan diketahui bahwa silabus yang dikembangkan rata-rata berkategori valid $(3,45)$ dan reliabel dengan tingkat reliabilitas mencapai 92,75\% (reliabel). Hal tersebut didasari oleh Borich yang menyatakan bahwa perangkat pembelajaran dikatakan reliabel apabila memiliki reliabilitas $75 \%{ }^{16}$.

\section{Hasil Validasi Rencana Pelaksanaan Pembelajaran (RPP)}

RPP yang dikembangkan dalam penelitian ini mengacu pada Permendikbud Nomor 81A Tahun 2013 tentang Implementasi Kurikulum, dimana pada Permendikbud tersebut disebutkan bahwa RPP paling sedikit memuat: (a) tujuan pembelajaran, (b) materi pembelajaran, (c) metode pembelajaran, (d) sumber belajar, dan (e) penilaian. Selain itu, dalam langkah kegiatan pembelajaran peneliti menggunakan sintaks model inkuiri terbimbing. Sintaks model inkuiri terbimbing meliputi: (i) perencanaan, (ii) mendapatkan informasi, (iii) memproses informasi, (iv) membuat informasi, (v) mengkomunikasikan informasi, dan (vi) mengevaluasi ${ }^{17}$. Dalam kelima tahapan tersebut terkandung aktivitas 5M yaitu: mengamati, menanya, mengumpulkan informasi, mengasosiasi, dan mengkomunikasikan.

Berdasarkan data dan analisis data hasil valiadasi RPP yang dilakukan menunjukkan bahwa RPP yang dikembangkan peneliti termasuk dalam kategori valid $(3,48)$ dengan sedikit revisi sehingga dapat digunakan. Hal tersebut disebabkan RPP yang dikembangkan telah memenuhi semua komponen penilaian. Adapun komponen penilaian RPP itu sendiri meliputi: identitas RPP, tujuan pembelajaran, model dan metode pembelajaran, kegiatan pembelajaran (pendahuluan, kegiatan inti, dan penutup), sumber dan media pembelajaran, serta evaluasi, semuanya mendapatkan skor rata-rata 3,48 dengan kategori valid dan tingkat reliabilitas mencapai 91,93\% (reliabel). Hal tersebut sejalan dengan pendapat Borich yang mengatakan bahwa instrumen dikatakan reliabel bila reliabilitasnya $\geq 0,75$ atau $75 \%{ }^{18}$.

\footnotetext{
${ }^{16}$ Borich, G. D. (1994). Observation skill for effective teaching. New York: Macmillan Publising Company

${ }^{17}$ Branch, J. and Oberg, D. (2004). Focus on inquiry a teacher guide to implementing inquiry based learning. Canada: Alberta Education, Alberta

${ }^{18}$ Ibid
} 


\section{Hasil Validasi Buku Ajar Siswa}

Buku ajar merupakan pedoman bagi guru untuk membimbing siswa dalam kegiatan pembelajaran, dan buku ajar juga digunakan sebagai pedoman siswa untuk melakukan atau mengikuti pembelajaran serta sebagai landasan siswa untuk melakukan kegiatan inkuiri. Analisis hasil validasi buku ajar siswa yang dilakukan oleh validator menyatakan bahwa buku ajar siswa yang dikembangkan adalah sangat valid dan dapat digunakan dengan sedikit revisi. Hal tersebut disebabkan buku ajar siswa yang dikembangkan telah memenuhi semua komponen penilaian yang meliputi: komponen kelayakan isi, komponen bahasa, koherensi dan kerunutan alur pikir, dan komponen penyajian dengan jumlah skor rata-rata 3,39 (sangat valid) dan tingkat reliabilitas mencapai 92,92\%. Hal tersebut sejalan dengan pendapat Borich yang menyatakan bahwa instrumen dikatakan reliabel bila reliabilitasnya $\geq 0,75$ atau $75 \%{ }^{19}$.

\section{Hasil Validasi Lembar Kerja Siswa (LKS)}

LKS yang dikembangkan memuat alur kegiatan pembelajaran model inkuiri terbimbing yang merangsang kemampuan siswa untuk berpikir kritis. Terdapat empat komponen yang dinilai dalam penyusunan LKS, yaitu: syarat didaktif, kelayakan isi, prosedur, dan pertanyaan dengan jumlah skor rata-rata mencapai 3,54 (valid) dengan tingkat reliabilitas mencapai 91,51\%. Berdasarkan hal tersebut LKS yang dikembangkan oleh peneliti termasuk dalam kategori valid dan reliabel. Pencapaian tingkat reliabilitas tersebut telah melewati standar reliabilitas yang telah ditetapkan sebesar 0,75 atau $75 \%^{20}$.

\section{Hasil Validasi Tes Pemahaman Konsep}

Tes pemahaman konsep dikembangkan untuk mengukur pemahaman konsep siswa sebelum dan setelah model pembelajaran inkuiri terbimbing diimplementasikan. Hasil validasi tes pemahaman konsep berkategori valid (sedikit revisi) dengan jumlah skor rata-rata mencapai 3,5 (valid) dan tingkat reliabilitas mecapai $85,71 \%$ (reliabel). Faktor utama yang menunjang kevalidan instrumen tes pemahaman konsep adalah kesesuaian antara rumusan tujuan pembelajaran yang akan dicapai dengan rumusan soal yang telah dirumuskan, sehingga mampu mengukur tujuan pembelajaran yang hendak dicapai. Pencapaian tingkat reliabilitas tersebut telah melewati standar reliabilitas yang telah ditetapkan sebesar 0,75 atau $75 \%{ }^{21}$. Berdasarkan hal yang demikian, tes pemahaman konsep dapat digunakan untuk mengukur pemahaman konsep siswa.

\section{Hasil Validasi Tes Keterampilan Berpikir Kritis}

Tes keterampilan berpikir kritis dikembangkan untuk mengukur keterampilan siswa dalam berpikir kritis sebelum dan setelah model pembelajaran inkuiri terbimbing diimplementasikan. 
Hasil validasi tes keterampilan berpikir kritis berkategori valid (sedikit revisi) dengan jumlah skor rata-rata mencapai 3,5 (valid) dan tingkat reliabilitas mecapai 85,71\% (reliabel). Faktor utama yang menunjang kevalidan instrumen tes keterampilan berpikir kritis adalah kesesuaian antara rumusan tujuan pembelajaran yang akan dicapai dengan rumusan soal yang telah dirumuskan, sehingga mampu mengukur tujuan pembelajaran yang hendak dicapai. Pencapaian tingkat reliabilitas tersebut telah melewati standar reliabilitas yang telah ditetapkan sebesar 0,75 atau 75\%. Berdasarkan hal tersebut tes keterampilan berpikir kritis layak digunakan untuk mengukur keterampilan berpikir kritis siswa.

\section{Kepraktisan Perangkat Pembelajaran}

Kepraktisan perangkat pembelajaran kimia yang dikembangkan dilihat dari: Pertama, Keterlaksanaan Pembelajaran, Kegiatan pembelajaran yang diterapkan merupakan pembelajaran yang menggunakan model inkuiri terbimbing. Keterlaksanaan kegiatan pembelajaran yang diamati meliputi aktivitas guru selama kegiatan pembelajaran berlangsung, pengelolaan waktu, dan suasana kelas.

Tabel 2.

Hasil Pengamatan Keterlaksanaan RPP

\begin{tabular}{|l|l|c|l|}
\hline No. & $\begin{array}{l}\text { Aspek yang } \\
\text { diamati }\end{array}$ & $\begin{array}{c}\text { Rata-rata } \\
\text { Hasil } \\
\text { Pengamatan }\end{array}$ & Keterang \\
\hline 1. & Pendahuluan & 4 & $\begin{array}{l}\text { Sangat } \\
\text { Baik }\end{array}$ \\
\hline 2. & $\begin{array}{l}\text { Kegiatan } \\
\text { Inti }\end{array}$ & 3,9 & $\begin{array}{l}\text { Sangat } \\
\text { Baik }\end{array}$ \\
\hline 3. & $\begin{array}{l}\text { Kegiatan } \\
\text { Penutup }\end{array}$ & $\begin{array}{l}\text { Pengelolaan } \\
\text { Waktu }\end{array}$ & $\begin{array}{l}\text { Sangat } \\
\text { Baik }\end{array}$ \\
\hline 4. & 4 & $\begin{array}{l}\text { Sangat } \\
\text { Baik }\end{array}$ \\
\hline 5. & $\begin{array}{l}\text { Suasana } \\
\text { Kelas }\end{array}$ & $\begin{array}{l}\text { Sangat } \\
\text { Baik }\end{array}$ \\
\hline & Rata-rata & $\begin{array}{l}\text { Sangat } \\
\text { Baik }\end{array}$ \\
\hline
\end{tabular}


Secara ringkas Tabel 2 menunjukkan hasil analisis data pengamatan terhadap keterlaksanaan RPP yang diamati oleh dua orang pengamat dihasilkan rata-rata skor keterlaksanaan RPP secara keseluruhan sebesar 3,98 dengan kategori sangat baik dan tingkat rata-rata reliabilitas keterlaksanaan RPP mencapai 98,5\%. Hal tersebut dilandasi oleh pendapat Ratumana \& Laurens yang mengatakan bahwa keterlaksanaan RPP dikatakan sangat baik bila memiliki nilai rata-rata keterlaksanaan berkisar antara 3,6 sampai dengan 4,0 22 . Sementara itu, pencapaian tingkat reliabilitas tersebut telah melewati standar yang telah ditetapkan yaitu sebesar 0,75 atau $75 \%$. Adapun sintaks pembelajaran inkuiri terbimbing yang digunakan untuk mengembangkan RPP berlandaskan pada sintaks inkuiri terbimbing yang ditetapkan oleh Branch \& Oberg RPP yang dikembangkan terbagi dalam tiga jenis kegiatan yaitu pendahuluan, kegiatan inti, dan penutup ${ }^{23}$.

Skor rata-rata keterlaksanaan yang tinggi dengan kategori sangat baik tersebut diperoleh karena semua tahap pembelajaran terlaksana dengan uraian sebagai berikut. Pertama, pada kegiatan pendahuluan; ketika fase Planning guru memulai pembelajaran dengan mengajak siswa berdo'a untuk menanamkan kesadaran dan rasa syukur atas kebesaran Tuhan YME., guru memotivasi siswa untuk melaksanakan proses belajar mengajar dan mengamati gejala alam yang berkaitan dengan struktur tubuh, guru menjelaskan tujuan pembelajaran, guru membagi LKS dan siswa dalam beberapa kelombok. Berdasarkan hasil pengamatan yang dilakukan oleh kedua pengamat, semua kegiatan yang terdapat pada bagian pendahuluan telah dilakukan dengan baik oleh peneliti. Hal tersebut menyebabkan guru bisa berhasil dalam membimbing siswa untuk menyiapkan diri dalam kegiatan penyelidikan sehingga siswa secara aktif ikut berpartisipasi dalam kegiatan pembelajaran agar siswa dapat menemukan suatu konsep. Hal tersebut sesuai dengan teori belajar penemuan oleh Bruner yang menyatakan bahwa dalam pembelajaran hendaknya mendorong siswa untuk aktif terlibat dengan konsep-konsep dan prinsip-prinsip agar mereka memperoleh dan melakukan eksperimen yang memungkinkan mereka menemukan prinsip-prinsip ${ }^{24}$.

Kedua, pada kegiatan inti, terdapat empat fase yang dilakukan oleh guru yaitu retrieving, processing, creating, dan sharing. Berdasarkan hasil pengamatan keterlaksanaan RPP yang dilakukan oleh dua pengamatan, keempat fase tersebut dilakukan peneliti dengan sangat baik sehingga keterlaksanaan RPP pada empat fase tersebut dikategorikan sangat baik. Perolehan kategori yang sangat baik tersebut dikarenakan pada fase retrieving, guru memberikan permasalahan kepada siswa untuk merangsang siswa bertanya. Guru membimbing melalui analogi

\footnotetext{
${ }^{22}$ Ratumanan, T.G. dan Laurens, T. (2011). Penilaian hasil belajar pada tingkat satuan pendidikan edisi 2. Surabaya: UNESA University Press

${ }^{23}$ Branch, J. and Oberg, D. (2004). Focus on inquiry a teacher guide to implementing inquiry based learning. Canada: Alberta Education, Alberta

${ }^{24}$ Slavin, R.E. (2011a). Psikologi pendidikan teori dan praktek, Edisi kesembilan jilid 1, diterjemahkan oleh Samosir, M. USA: Pearson
} 
dan pertanyaan agar siswa mengumpulkan informasi dan mampu menanya yang dituangkan dalam rumusan masalah. Setelah itu, guru membimbing siswa agar dapat merumuskan hipotesis. Melalui kegiatan menanya yang dituangkan dalam rumusan masalah ini, menunjukkan bahwa siswa memiliki motivasi yang tinggi dalam mengikuti pembelajaran yang menggunakan model inkuiri terbimbing, karena model pembalajaran inkuiri terbimbing dapat menigkatkan motivasi belajar siswa dan dapat mendorong siswa untuk memiliki semangat inisiatif ${ }^{25}$. Hal itu juga yang menunjukkan bahwa dalam pembelajaran ini, peneliti menggunakan model inkuiri terbimbing. Hal tersebut sesuai dengan karakteristik dari pembelajaran inkuiri terbimbing yaitu pembelajaran terikat pada pertanyaan (siswa maupun guru) yang berbasis ilmiah dan diakhiri dengan jawaban ${ }^{26}$. Karakteristik tersebut mendapat dukungan dari Zion \& Sadeh yang menjelaskan bahwa pusat pembelajaran inkuiri terbimbing adalah mengajukan pertanyaan tentang gejala alam dan menemukan jawaban terhadap pertanyaan tersebut ${ }^{27}$.

Pada fase processing, guru membimbing melalui pertanyaan agar siswa tepat waktu dalam mempersiapkan, dan melaksanakan percobaan dengan jujur, tanggung jawab, dan kehati-hatian. Kegiatan percobaan bertujuan untuk memberikan kesempatan kepada siswa untuk berinteraksi dengan objek permasalahan yang telah diberikan oleh guru. Hal tersebut didasari oleh pandangan teori konstruktivis yang menyatakan bahwa siswa yang berinteraksi dengan objek dan peristiwa dapat memperoleh informasi dan memahami pola-pola pengamatan terhadap objek dan peristiwa ${ }^{28}$. Pandangan teori konstruktivis tersebut diperkuat oleh Piaget yang menyatakan bahwa pengetahuan diperoleh melalui tindakan.

Pada fase creating, guru membimbing siswa agar mampu menalar dengan menganalisis data hasil eksperimen dan menjawab pertanyaan LKS dengan penuh ketelitian dan tanggung jawab. Kemudian, guru membimbing melalui analogi dan pertanyaan agar siswa membentuk jejaring pengetahuan melalui kegiatan menyimpulkan hasil percobaan dengan penuh kejujuran dan tanggung jawab. Pada fase ini siswa dibimbing untuk menganalisis data hasil percobaan yang diperoleh, selanjutnya melalui hasil analisis data percobaan tersebut siswa dibimbing untuk merumuskan kesimpulan. Penerapan pembelajaran yang menggunakan inkuiri terbimbing tidak hanya dapat meningkatkan kemampuan siswa dalam menguasai konsep tetapi juga dapat

${ }^{25}$ Berg, C. A. R., Bergendahl, V. C. B. and Lundberg, B. K. S. (2003). "Benefiting from an open-ended experiment? A comparison of attitudes to, and outcomes of, an expository versus an open-inquiry version of the same experiment”. International journal of science education. Vol. 25 No. 3, pp. 112-121

${ }^{26}$ Olson, S. \& Horsley, S.L. (2011). Inkuiri dan standar-standar pendidikan sains nasional sebuah panduan untuk pengajaran dan pembelajaran, diterjemahkan oleh Ismunandar, Agustiani, E.D. dan Astuti D.R.F. Washington D.C.: National Academy Press

${ }^{27}$ Zion, M. and Sadeh, I. (2011). "Curiosity and open inquiry learning”. JBE. Vol. 41 No. 4, pp. 162-169

${ }^{28}$ Asrori, M. (2012). Psikologi pembelajaran. Bandung: Wacana Prima 
meningkatkan keterampilan proses (pada fase ini terdapat dua indikator keterampilan proses yaitu menganalisis data dan merumuskan kesimpulan) dan dapat menumbuhkan nilai karakter siswa ${ }^{29}$.

Pada fase sharing, guru memberikan kesempatan perwakilan kelompok menyajikan dan mengkomunikasikan hasil percobaan dengan jujur dan bertanggung jawab. Setelah itu, guru mengomentari jalannya diskusi dan memberikan penguatan serta meluruskan yang kurang tepat. Pada fase sharing ini, melalui kegiatan mengkomunikasikan hasil percobaan dan diskusi akan terjadi interaksi sosial antara siswa dengan siswa, dan antara guru dengan siswa. Melalui interaksi sosial tersebut siswa bisa melakukan kegiatan belajar. Hal tersebut sesuai dengan teori kognisi sosial oleh Vigotsky yang menyatakan bahwa siswa belajar melalui interaksi dengan orang dewasa dan teman sebayanya yang lebih mampu. Lebih lanjut, interaksi sosial tersebut akan memacu terbentuknya ide baru dan akan meningkatkan intelektual siswa sehingga zona perkembangan terdekatnya (ZPD) semakin besar ${ }^{30}$.

Ketiga, kegiatan penutup terdapat fase terakhir dari inkuiri terbimbing yang diadaptasi dari Branch \& Oberg yaitu evaluating, pada fase ini guru membimbing siswa melalui analogi dan pertanyaan agar siswa membentuk jejaring pengetahuan membuat kesimpulan sesuai tujuan pembelajaran $^{31}$. Selanjutnya, guru memberikan permasalahan lanjutan berupa soal uji pemahaman konsep atau soal tes keterampilan berpikir kritis dan guru membimbing agar siswa mengerjakan soal dengan jujur, penuh tanggung jawab, dan hati-hati. Penggunaan pertanyaan berperan penting untuk memicu siswa untuk menemukan informasi tambahan untuk membangun pemahaman dan pengetahuan dengan lebih mudah dan lebih baik ${ }^{32}$.

Keempat, pengelolaan waktu, antusias siswa dan guru dalam pembelajaran menggunakan inkuiri terbimbing memperoleh kategori sangat baik. Hal ini menunjukkan bahwa peneliti dapat menghidupkan suasana kelas, sehingga kelas menjadi menyenangkan. Sistem pengelolaan waktu dan suasana kelas yang dilakukan peneliti harus tetap menjaga keterlibatan siswa agar siswa tetap memiliki antusias yang tinggi dalam mengikuti pembelajaran.

Berdasarkan uraian di atas dapat diketahui bahwa RPP yang dikembangkan peneliti dilaksanakan dengan sangat baik. Perangkat pembelajaran yang dikembangkan juga merupakan perangkat yang reliabel, sehingga kualitas pembelajaran yang dihasilkan juga akan semakin baik.

${ }^{29}$ Jannah, M., Sugianto, dan Sarwi. (2012). "Pengembangan perangkat pembelajaran berorientasi nilai karakter melalui inkuiri terbimbing materi cahaya pada siswa kelas VIII Sekolah Menengah Pertama". Journal of innovative science education. Vol. 1 No. 1 Juni, 2012, pp, 54-60

${ }^{30}$ Ibid

${ }^{31}$ Branch, J. and Oberg, D. (2004). Focus on inquiry a teacher guide to implementing inquiry based learning. Canada: Alberta Education, Alberta

${ }^{32}$ David, M.H. (2006). Instructor's guide to process-oriented guided-inquiry learning. SUNY: Stony Brook University 


\section{Aktivitas Siswa}

Berdasarkan hasil analisis data yang telah dilakukan yang secara ringkas ditunjukkan pada Tabel 3 diketahui bahwa aktivitas siswa selama proses pembelajaran menggunakan model inkuiri terbimbing menunjukkan frekuensi yang cukup stabil dengan kategori baik, dengan tingkat reliabilitas pada pertemua pertama dan pertemuan kedua mencapai $77 \%$ dan $76 \%$ (reliabel). Aktivitas siswa dikatakan reliabel apabila reliabilitasnya $\geq 75 \%{ }^{33}$. Hal tersebut disebabkan karena pada saat proses pembelajaran peneliti selalu melakasanakan skenario pembelajaran yang terdapat pada rencana pelaksanaan pembelajaran (RPP) yan dikembangkan dan menggunakan perangkat pembelajaran termasuk media atau alat yang dibutuhkan selama kegiatan pembelajaran.

\section{Tabel 3}

Persentase Aktivitas Siswa yang Menggunakan Model Inkuri Terbimbing

\begin{tabular}{|c|c|c|c|}
\hline \multirow{2}{*}{ No. } & \multirow{2}{*}{ Aktivitas Siswa } & \multicolumn{2}{|c|}{$\begin{array}{c}\text { Persentase } \\
(\%)\end{array}$} \\
\hline & & $\begin{array}{c}\text { Pert } \\
. \text { I }\end{array}$ & $\begin{array}{l}\text { Pert } \\
\text {. II }\end{array}$ \\
\hline 1. & $\begin{array}{l}\text { Menyimak penjelasan } \\
\text { guru }\end{array}$ & 9 & 10 \\
\hline 2. & $\begin{array}{l}\text { Menjawab pertanyaan } \\
\text { guru }\end{array}$ & 10 & 4 \\
\hline 3. & $\begin{array}{l}\text { Bertanya kepada guru } \\
\text { untuk } \\
\text { bimbingan }\end{array}$ & 10 & 9 \\
\hline 4. & Merumuskan masalah & 5 & 4 \\
\hline 5. & $\begin{array}{l}\text { Merumuskan hipotesis } \\
\text { percobaan }\end{array}$ & 7 & 4 \\
\hline 6. & Melakukan percobaan & 6 & 4 \\
\hline 7. & $\begin{array}{l}\text { Menganalisis data hasil } \\
\text { percobaan }\end{array}$ & 8 & 7 \\
\hline 8. & $\begin{array}{l}\text { Menjawab dan } \\
\text { menanggapi pertanyaan } \\
\text { diskusi }\end{array}$ & 6 & 2 \\
\hline 9. & Merumuskan kesimpulan & 5 & 4 \\
\hline
\end{tabular}

${ }^{33}$ Borich, G. D. (1994). Observation skill for effective teaching. New York: Macmillan Publising Company 


\begin{tabular}{|c|l|c|c|}
\hline 10. & $\begin{array}{l}\text { Menyajikan dan } \\
\text { mengkomunikasikan } \\
\text { hasil percobaan }\end{array}$ & 6 & 2 \\
\hline 11. & $\begin{array}{l}\text { Mengerjakan koal } \\
\text { pemahaman konsep dan } \\
\text { soal keterampilan } \\
\text { berpikir kritis }\end{array}$ & 2 & 4 \\
\hline Reliabilitas & $\mathbf{7 7}$ & $\mathbf{7 6}$ \\
\hline
\end{tabular}

Hasil analisis yang telah dilakukan menunjukkan bahwa pembelajaran yang menggunakan inkuiri terbimbing sejalan dengan anjuran dari teori belajar konstruktivis yang menyatakan bahwa dalam pembelajaran siswa dituntut untuk berperan lebih aktif agar terjadi pembelajaran yang berpusat pada siswa. Hal tersebut mendapat dukungan dari Zion \& Sadeh yang menyatakan bahwa melalui pembelajaran inkuiri terbimbing siswa harus terlibat secara aktif dalam proses pembelajaran agar siswa dapat membangun keterampilan berpikir mereka sendiri ${ }^{34}$.

\section{Keefektifan Perangkat Pembelajaran}

Keefektifan perangkat pembelajaran kimia yang dikembangkan dilihat dari: (1) Keterampilan Berpikir Kritis, Keterampilan berpikir kritis yang dimaksud dalam penelitian ini adalah merumuskan masalah, memberi argumen, melakukan evaluasi, dan menyimpulkan. Nilai pre test digunakan untuk mengetahui sejauh mana keterampilan siswa dalam berpikir kritis. Sedangkan nilai post test digunakan untuk mengetahui keterampilan berpikir kritis siswa setelah mengikuti pelatihan keterampilan berpikir kritis melalui pembelajaran yang menggunakan model inkuiri terbimbing. Sehigga dengan demikian, dapat diketahui tentang bisa atau tidaknya melatihkan keterampilan berpikir kritis siswa melalui pembelajaran yang menggunakan inkuiri terbimbing. Sensitivitas soal digunakan untuk mengukur seberapa baik butir soal itu membedakan tingkat keterampilan siswa dalam berpikir kritis baik sebelum dan sesudah menerima pembelajaran ${ }^{35}$. Dalam penelitian ini hasil analisis data menunjukkan bahwa semua soal keterampilan berpikir kirits yang dikembangkan mendapat nilai sensitivitas berkisaran antara 0,4 sampai dengan 0,8. ${ }^{36}$ Butir soal yang efektif memiliki indeks sensitivitas $\geq 0,30$. Dengan demikian soal tes keterampilan berpikir kritis yang telah dikembangkan layak digunakan untuk mengukur keterampilan berpikir kritis siswa terhadap $\begin{array}{lllll}\text { materi } & \text { reaksi truktur tubuh dalam }\end{array}$

\footnotetext{
${ }^{34}$ Zion, M. and Sadeh, I. (2011). "Curiosity and open inquiry learning”. JBE. Vol. 41 No. 4, pp. 162-169

${ }^{35}$ Okonkwo \& Osuji. (2006). Measurement and evaluation. Nigeria: National Open University of Nigeria.

${ }^{36}$ Gronlund, N.E. (1985). Constructing achievement test. $5^{\text {th }}$ Edition. New York: Prentice Hall Inc
} 
Tabel 5.

Skor Peningkatan (Gain) keterampilan Berpikir Kritis Siswa

\begin{tabular}{|c|c|c|c|c|c|c|}
\hline \multirow{2}{*}{$\begin{array}{c}\text { No. Urut } \\
\text { Siswa }\end{array}$} & \multicolumn{2}{|c|}{ Pre Test } & \multicolumn{2}{|c|}{ Post Test } & \multirow{2}{*}{$\begin{array}{c}\text { Skor } \\
\text { Peningkata } \\
\text { n (Gain) }\end{array}$} & \multirow{2}{*}{$\begin{array}{c}\text { Kategor } \\
\text { i }\end{array}$} \\
\hline & Skor & $\begin{array}{c}\text { \% Rata- } \\
\text { rata }\end{array}$ & Skor & $\begin{array}{c}\text { \% Rata- } \\
\text { rata }\end{array}$ & & \\
\hline 1 & 10 & 35,71 & 21 & 75,00 & 0,6 & Sedang \\
\hline 2 & 17 & 60,71 & 19 & 67,86 & 0,2 & Rendah \\
\hline 3 & 7 & 25,00 & 23 & 82,14 & 0,8 & Tinggi \\
\hline 4 & 18 & 64,29 & 20 & 71,43 & 0,2 & Rendah \\
\hline 5 & 13 & 46,43 & 23 & 82,14 & 0,7 & Tinggi \\
\hline 6 & 14 & 50,00 & 23 & 82,14 & 0,6 & Sedang \\
\hline 7 & 11 & 39,29 & 21 & 75,00 & 0,6 & Sedang \\
\hline 8 & 19 & 67,86 & 20 & 71,43 & 0,1 & Rendah \\
\hline 9 & 10 & 35,71 & 25 & 89,29 & 0,8 & Tinggi \\
\hline 10 & 14 & 50,00 & 23 & 82,14 & 0,6 & Sedang \\
\hline 11 & 7 & 25 & 24 & 87,71 & 0,8 & Tinggi \\
\hline 12 & 7 & 25 & 26 & 92,86 & 0,9 & Tinggi \\
\hline 13 & 9 & 32,14 & 24 & 85,71 & 0,8 & Tinggi \\
\hline 14 & 13 & 46,43 & 23 & 82,14 & 0,7 & Tinggi \\
\hline 15 & 7 & 25 & 25 & 89,29 & 0,9 & Tinggi \\
\hline 16 & 7 & 25 & 25 & 89,29 & 0,9 & Tinggi \\
\hline 17 & 7 & 25 & 23 & 82,14 & 0,8 & Tinggi \\
\hline 18 & 7 & 25 & 24 & 85,71 & 0,8 & Tinggi \\
\hline 19 & 18 & 64,29 & 25 & 89,29 & 0,7 & Tinggi \\
\hline 20 & 9 & 32,14 & 25 & 89,29 & 0,8 & Tinggi \\
\hline 21 & 12 & 42,86 & 26 & 92,86 & 0,9 & Tinggi \\
\hline 22 & 14 & 50 & 27 & 96,43 & 0,9 & Tinggi \\
\hline 23 & 12 & 42,86 & 25 & 89,29 & 0,8 & Tinggi \\
\hline 24 & 13 & 46,43 & 27 & 96,43 & 0,9 & Tinggi \\
\hline 25 & 14 & 50 & 27 & 96,43 & 0,9 & Tinggi \\
\hline 26 & 14 & 50 & 24 & 85,71 & 0,7 & Tinggi \\
\hline 27 & 9 & 32,14 & 24 & 85,71 & 0,8 & Tinggi \\
\hline 28 & 16 & 57,14 & 24 & 85,71 & 0,7 & Tinggi \\
\hline
\end{tabular}




\begin{tabular}{|c|c|c|c|c|c|c|}
\hline \multirow{2}{*}{$\begin{array}{c}\text { No. Urut } \\
\text { Siswa }\end{array}$} & \multicolumn{2}{|c|}{ Pre Test } & \multicolumn{2}{|c|}{ Post Test } & \multirow{2}{*}{$\begin{array}{c}\text { Skor } \\
\text { Peningkata } \\
\text { n (Gain) }\end{array}$} & \multirow[b]{2}{*}{$\begin{array}{c}\text { Kategor } \\
\text { i }\end{array}$} \\
\hline & Skor & $\begin{array}{c}\text { \% Rata- } \\
\text { rata }\end{array}$ & Skor & $\begin{array}{c}\text { \% Rata- } \\
\text { rata }\end{array}$ & & \\
\hline 29 & 16 & 57,14 & 22 & 78,57 & 0,5 & Sedang \\
\hline 30 & 7 & 25 & 23 & 82,14 & 0,8 & Tinggi \\
\hline Jumlah & 351 & 1253,57 & 711 & 2539,28 & 21,3 & \\
\hline $\begin{array}{l}\text { Rata- } \\
\text { rata }\end{array}$ & 11.7 & 41,79 & 23,7 & 84,64 & 0,71 & Tinggi \\
\hline
\end{tabular}

Berdasarkan hasil analisis data yang ditunjukkan pada tabel 5 skor peningkatan (gain) keterampilan berpikir kritis siswa menunjukkan bahwa nilai rata-rata peningkatan (gain) secara klasikal mencapai 0,71 dengan kategori tinggi. Peningkatan tersebut menunjukkan bahwa penerapan perangkat pembelajaran kimia yang dikembangkan menggunakan inkuri terbimbing efektif dalam melatihkan keterampilan berpikir kritis siswa pada meteri reaksi oksidasi-reduksi. hasil temuan dalam penelitian ini sesuai dengan hasil temuan dari penelitian yang pernah dilakukan oleh Rahma Bilgin yang menyimpulkan bahwa melalui pembelajaran inkuiri terbimbing dapat menumbuhkan kemampuan matematik, kemampuan verbal, keterampilan berpikir kritis, dan rasa empati siswa, serta dapat meningkatkan pemahaman konsep siswa yang lebih baik untuk melakukan penyelidikan $^{37}$.

\section{Hasil Pemahaman Konsep}

Nilai pre test siswa digunakan untuk mengetahui sejauh mana kemampuan siswa menguasai konsep reaksi oksidasi-reduksi sebelum mengikuti pembelajaran yang menggunakan model inkuiri terbimbing. Sedangkan nilai post test digunakan untuk mengetahui pemahaman siswa terhadap konsep reaksi oksidasi-reduksi setelah mengikuti pembelajaran yang menggunakan model inkuiri terbimbing. Berdasarkan data hasil rekapitulasi ketuntasan pemahaman konsep secara individu diketahui bahwa pada saat pre test dari 30 siswa hanya 4 siswa yang mecapai KKM (75). Sedangkan pada saat post test dari 30 siswa tersebut semuanya mencapai KKM (75). Peningkatan yang ditunjukkan oleh hasil analisis data yang telah dilakukan menunjukkan bahwa penerapan perangkat pembelajaran IPA yang dikembangkan menggunakan inkuiri terbimbing pada materi pokok reaksi redoks mampu meningkatkan pemahaman konsep siswa. Hal ini sejalan dengan hasil penelitian yang dilakukan oleh Bilgin yang menyimpulkan bahwa pembelajaran guided inkuiri (inkuiri terbimbing) dapat meningkatkan pemahaman konsep struktur tubuh siswa yang lebih baik

${ }^{37}$ Bilgin, I. (2009). "The effects of guided inquiry instruction incorporating a cooperative learning approach on university students' achievement of acid and bases concepts and attitude toward guided inquiry instruction". Academic journals. Vol. 4 No. 10, pp. 1038-1046 
untuk melakukan penyelidikan. Lebih lanjut Mainali menyimpulkan bahwa berpikir kritis dapat meningkatkan pemahaman, kemampuan memecahkan masalah, dan keterampilan berpikir kritis $\operatorname{siswa~}^{38}$.

Sensitivitas soal digunakan untuk mengukur seberapa baik butir soal itu membedakan tingkat kemampuan siswa memahami materi ajar sebelum dan sesudah menerima pembelajaran ${ }^{39}$. Dalam penelitian ini hasil analisis data yang telah dilakukan menunjukkan bahwa semua soal tes pemahaman konsep yang dikembangkan mendapat nilai sensitivitas berkisaran antara 0,3 sampai dengan 0,6. Butir soal yang efektif memiliki indeks sensitivitas $\geq 0,30$. Berdasarkan hal tersebut, soal tes pemahaman konsep yang telah dikembangkan layak digunakan untuk mengukur pemahaman konsep siswa terdahap materi Struktur tubuh pada pembelajaran IPA.

\section{Respon Siswa}

Siswa memberikan respon terhadap pembelajaran yang menggunakan inkuiri terbimbing berkategori baik, karena 57\% siswa sangat setuju dan 43 siswa setuju bahwa siswa merasa senang belajar menggunakan model inkuiri terbimbing, karena bisa langsung mengaplikasikan materi pembelajaran yang mereka peroleh; $40 \%$ siswa sangat setuju dan $60 \%$ siswa setuju bahwa dengan belajar menggunakan inkuiri terbimbing siswa lebih berani mengemukakan pendapatnya sehingga mereka lebih cepat memahami materi ajar; $40 \%$ siswa sangat setuju dan $60 \%$ siswa setuju bahwa melalui pembelajaran yang menggunakan inkuiri terbimbing siswa merasa lebih aktif dalam proses pembelajaran; 97\% sangat setuju dan 3\% setuju bahwa motivasi belajarnya meningkat dengan pembelajaran yang menggunakan inkuiri terbimbing; $43 \%$ siswa sangat setuju dan $57 \%$ siswa setuju bahwa melalui pembelajaran inkuiri terbimbing siswa lebih mudah mengerjakan soal-soal; 57\% siswa sangat setuju dan $43 \%$ siswa setuju bahwa pembelajaran yang menggunakan inkuiri terbimbing tidak membosankan; 97\% siswa sangat setuju dan 3\% siswa setuju melalui pembelajaran yang menggunakan inkuiri terbimbing dapat melatih keterampilan berpikir kritisnya; dan $57 \%$ siswa sangat setuju dan $43 \%$ siswa setuju bahwa melalui pembelajaran yang menggunakan inkuiri tebimbing dapat meningkatkan pemahaman konsepnya.

Hal tersebut sesuai dengan pendapat Crockett menyatakan bahwa penerapan model inkuiri terbimbing memberi keuntungan yang dapat meningkatkan motivasi belajar siswa, dan meningkatkan pemahaman siswa tentang proses, konsep, dan hubungannya ${ }^{40}$.

\footnotetext{
${ }^{38}$ Mainali, B.P. (2011). “Critical thinking for quality education”. Academic voices a multidisciplinary journal. Vol. 1 NO. 1

${ }^{39}$ Okonkwo \& Osuji. (2006). Measurement and evaluation. Nigeria: National Open University of Nigeria

${ }^{40}$ Crawford, B. A. (2000). "Embracing the essence of inquiry: new roles for science teachers". Journal of research in science teaching. Vol. 37 No. 9, pp. 916-937
} 


\section{Kendala atau Hambatan Selama Proses Pembelajaran}

Selama melaksanakan pembelajaran menggunakan inkuiri terbimbing, peneliti menemukan beberapa kendala atau hambatan. Hambatan atau kendala pertama kurangnya alat-alat praktikum yang diperlukan. Kendala tersebut diatasi dengan membentuk kelompok dengan jumlah yang lebih banyak. Kendala kedua siswa belum terbiasa mengerjakan LKS yang dikembangkan (terutama membuat rumusan masalah dan rumusan hipotesis) sehingga siswa membutuhkan arahan dan bimbingan yang lebih banyak dalam mengerjakan LKS. Solusi yang diberikan untuk menagani kendala atau tersebut peneliti memberikan arahan dan bimbingan kepada siswa sebelum mengerjakan soal.

\section{Simpulan}

Berdasarkan diskusi hasil penelitian dapat disimpulkan bahwa perangkat pembelajaran IPA yang dikembangkan menggunakan model inkuiri terbimbing pada pokok bahasan struktur tubuh layak untuk melatih keterampilan berpikir kritis siswa.

\section{Daftar Pustaka}

Asrori, M. (2012). Psikologi pembelajaran. Bandung: Wacana Prima.

Astuti Y. \& Setiawan, B. (2013). "Pengembangan lembar kerja siswa (LKS) berbasis pendekatan inkuiri terbimbing dalam pembelajaran kooperatif pada materi kalor”. Jurnal pendidikan IPA Indonesia. Vol. 2. No.1, pp. 88-92.

Berg, C. A. R., Bergendahl, V. C. B. and Lundberg, B. K. S. (2003). "Benefiting from an open-ended experiment? A comparison of attitudes to, and outcomes of, an expository versus an open-inquiry version of the same experiment”. International journal of science education. Vol. 25 No. 3, pp. 112-121.

Bilgin, I. (2009). "The effects of guided inquiry instruction incorporating a cooperative learning approach on university students' achievement of acid and bases concepts and attitude toward guided inquiry instruction". Academic journals. Vol. 4 No. 10, pp. 1038-1046.

Borich, G. D. (1994). Observation skill for effective teaching. New York: Macmillan Publising Company.

Branch, J. and Oberg, D. (2004). Focus on inquiry a teacher guide to implementing inquiry based learning. Canada: Alberta Education, Alberta.

BSNP. (2013). Permendikbud Nomor 81A tahun 2013 tentang implementasi kurikulum. Jakarta: BSNP.

Crawford, B. A. (2000). "Embracing the essence of inquiry: new roles for science teachers". Journal of research in science teaching. Vol. 37 No. 9, pp. 916-937.

David, M.H. (2006). Instructor's guide to process-oriented guided-inquiry learning. SUNY: Stony Brook University.

Dewi, Sadia, \& Ristiati. (2013). "Pengembangan perangkat pembelajaran IPA terpadu dengan setting inkuiri terbimbing untuk meningkatkan pemahaman konsep dan kinerja ilmiah". E-Journal program pascasarjana universitas pendidikan ganesha. Vol 3 Tahun 2013.

Firdaus, L. (2014). Pengembangan perangkat pembelajaran sains berorientasi pada guided inquiry untuk memberdayakan keterampilan berpikir dan pemahaman konsep siswa SMP (Tesis magister pendidikan tidak dipublikasikan). Universitas Negeri Surabaya.

Fraenkel, J. R., and Wallen, N. E., (2009). How to design and evaluate research in education seventh edition. New York: McGraw-Hill Higher Education. 
Gronlund, N.E. (1985). Constructing achievement test. $5^{\text {th }}$ Edition. New York: Prentice Hall Inc.

Ibrahim, M. (2008). Model pembelajaran inovatif IPA melalui pemaknaan”. UNESA. Surabaya: Tim Balitbang Diknas.

Ibrahim, M. (2014). “Inovasi pendidikan sains dalam kurikulum 2013”. Makalah disajikan pada Seminar Nasional Pendidikan Sains, Surabaya, Tanggal 18 Januari 2014.

Jannah, M., Sugianto, dan Sarwi. (2012). "Pengembangan perangkat pembelajaran berorientasi nilai karakter melalui inkuiri terbimbing materi cahaya pada siswa kelas VIII Sekolah Menengah Pertama". Journal of innovative science education. Vol. 1 No. 1 Juni, 2012, pp, 54-60.

Johnson, E.B. (2008). Contextual teaching \& learning. Bandung: MLC.

Krisnawati, N.M. (2014). Pengembangan perangkat pembelajaran biologi model kooperatif dengan pendekatan scientific untuk melatih berpikir kritis siswa SMA (Tesis magister pendidikan tidak dipublikasikan). Universitas Negeri Surabaya.

Luft, J. (2001). "Changing inquiry practices and beliefs: The impact of an inquiry-based professional development programs on beginning and experienced secondary science teachers". International journal of science education. Vol. 23 No. 5, pp. 517-534.

Mainali, B.P. (2011). "Critical thinking for quality education”. Academic voices a multidisciplinary journal. Vol. 1 N0. 1.

Mulyasa. (2013). Pengembangan dan implementasi kurikulum 2013. Bandung: Remaja Rosdakarya.

Nebraska Department of Education. (2007). $21^{\text {st }}$ Century Education Frame Work, www.21st-centuryskills.org.

Norris, S.P. (1985). “Synthesis of Research on Critical Thinking”. Educational Leadership. 1985. Pp.40-45.

Okonkwo \& Osuji. (2006). Measurement and evaluation. Nigeria: National Open University of Nigeria.

Olson, S. \& Horsley, S.L. (2011). Inkuiri dan standar-standar pendidikan sains nasional sebuah panduan untuk pengajaran dan pembelajaran, diterjemahkan oleh Ismunandar, Agustiani, E.D. dan Astuti D.R.F. Washington D.C.: National Academy Press.

Ratumanan, T.G. dan Laurens, T. (2011). Penilaian hasil belajar pada tingkat satuan pendidikan edisi 2. Surabaya: UNESA University Press.

Slavin, R.E. (2011a). Psikologi pendidikan teori dan praktek, Edisi kesembilan jilid 1, diterjemahkan oleh Samosir, M. USA: Pearson.

Slavin, R.E. (2011b). Psikologi pendidikan teori dan praktek, Edisi kesembilan jilid 2, diterjemahkan oleh Samosir, M. USA: Pearson.

Wasis. (2015). “Hasil Pembelajaran Sains di Indonesia: Problem dan Upaya Mengatasinya”. Makalah disajikan pada Seminar Nasional Pendidikan Sains, Surabaya, Tanggal 24 Januari 2015.

Zion, M. and Sadeh, I. (2011). "Curiosity and open inquiry learning”. JBE. Vol. 41 No. 4, pp. 162-169. 